\title{
Effects of coumestrol administration to pregnant and lactating mice on intestinal alkaline phosphatase activity.
}

\section{$\operatorname{AUTHOR}(S)$ :}

Kirihata, Yuka; Horiguchi, Yoshihiro; Ueda, Michihisa; Sugimoto, Miki; Ikeda, Shuntaro; Kume, Shinichi

\section{CITATION:}

Kirihata, Yuka ... [et al]. Effects of coumestrol administration to pregnant and lactating mice on intestinal alkaline phosphatase activity.. Phytotherapy research 2010, 25(5): 654658

\section{ISSUE DATE:}

2010-10-28

URL:

http://hdl.handle.net/2433/197177

\section{RIGHT:}

This is the peer reviewed version of the following article: Kirihata, Y., Horiguchi, Y., Ueda, M., Sugimoto, M., Ikeda, S. and Kume, S. (2011), Effects of coumestrol administration to pregnant and lactating mice on intestinal alkaline phosphatase activity. Phytother. Res., 25: 654-658, which has been published in final form at http://dx.doi.org/10.1002/ptr.3317; This is not the published version. Please cite only the published version.; この論文は出版社版でありません。引用の際には 出版社版をご確認じ利用ください。 


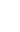

\section{Effects of Coumestrol Administration to Pregnant and Lactating}

\section{Mice on Intestinal Alkaline Phosphatase Activity}

Yuka Kirihata, Yoshihiro Horiguchi, Michihisa Ueda, Miki Sugimoto, Shuntaro Ikeda, and Shinichi Kume* Graduate School of Agriculture, Kyoto University, Kyoto 606-8502, Japan

Correspondence author: Shinichi Kume,

Graduate School of Agriculture, Kyoto University, Sakyo-ku, Kyoto

606-8502, Japan
Tel) +81-75-753-6325, Fax)+81-75-753-6345,
E-mail: kume@kais.kyoto-u.ac.jp

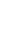

\footnotetext{
* Corresponding author to: Prof. Shinichi Kume, Graduate School of Agriculture, Kyoto University, Sakyo-ku, Kyoto 606-8502, Japan e-mail: kume@kais.kyoto-u.ac.jp
} 
The present study was conducted to clarify the effects of coumestrol administration during pregnancy on Ca metabolism during pregnancy and in lactating mice. From 6.5 to 16.5 days post coitus (dpc), pregnant mice were administered at $200 \mu \mathrm{g} / \mathrm{kg}$ body weight/day of coumestrol. The duodenum, jejunum and blood samples were obtained at 17.5 dpc or 10 days after parturition (dap). Coumestrol administration decreased alkaline phosphatase (ALP) activity and mRNA expression of IAP and estrogen responsive genes, $c$-fos and vascular endothelial growth factor (VEGF), in the duodenum and jejunum of pre-delivery mice. In lactating mice, the ALP activity and mRNA expression of IAP were not changed, although coumestrol administration decreased mRNA expression of $c$-fos in the duodeum and VEGF in the jejunum. Coumestrol did not affect serum Ca and the expression of vitamin D receptor protein in the duodenum and jejunum. Thus, coumestrol administration during pregnancy may decrease the mRNA expression of IAP and the ALP activity in the intestine of the pre-delivery mice through $\mathrm{ER} \alpha$, but coumestrol had little effect on intestinal ALP activity at 10 days after parturition.

Keywords; coumestrol: alkaline phosphatase: Ca metabolism; pre-delivery mice 


\section{INTRODUCTION}

Phytoestrogens are plant-derived compounds that have similar chemical structures to endogenous estrogens and the potential to mimic estrogen activity (Ososki and Kennelly, 2003). These chemicals can compete with $17 \beta$-estradiol for binding to estrogen receptors (ERs), although their relative affinity to ERs and transcription activity are substantially less than those of endogenous estrogens. Because phytoestrogens may help to prevent carcinomas, heart diseases, osteoporosis and menopausal disorders (Ososki and Kennelly, 2003), it is expected that the phytoestrogens can be used for estrogen replacement therapy to improve the health status of humans and animals.

Coumestrol, a phytoestrogen and the most prevalent coumestan derivatives, interacts with ERs most strongly in phytoestrogens and has various physiological effects through ERs in vivo and in vitro (Morito et al., 2002). Ca plays a crucial role in some targeted organs, and the demands for fetal accretion of $\mathrm{Ca}$ and output of milk are met by physiological changes in Ca metabolism during pregnancy and lactation, such as renal Ca conservation, increased Ca resorption from the skeleton or enhanced Ca absorption (Kovacs and Kronenberg, 1997). Estrogen plays some physiological role in Ca homeostasis through intestine, kidney and bone (Farhan and Sundeep, 2005). Coumestrol stimulates bone cells and exerts effective prevention against bone resorption in estrogen deficient rats (Ye et al., 2003).

Phytoestrogens can act as both estrogen agonists and antagonists (Ososki and Kennelly, 2003). The effects of oral administration of coumestrol at doses of 0.1 to 30 $\mathrm{mg} / \mathrm{kg}$ body weight have been examined in ovariectomized rats; $\geq 1 \mathrm{mg} / \mathrm{kg}$ body weight of coumestrol increased uterine weight, $\geq 10 \mathrm{mg} / \mathrm{kg}$ body weight increased bone mineral density of the tibia, and $\geq 100 \mu \mathrm{g} / \mathrm{kg}$ body weight lowered cholesterol in sera 
significantly (Dodge et al., 1996). As of August 23, 2006, the Ministry of Health, Labour and Welfare of Japan recommends intake of up to $30 \mathrm{mg}$ per day of soybean isoflavone. This corresponds to about $458-570 \mu \mathrm{g} / \mathrm{kg}$ body weight/day on the average body weight of Japanese adults. Based on less than half this limit for isoflavone intake, we previously examined the effects of coumestrol on Ca metabolism in the post-delivery mice given $200 \mu \mathrm{g} / \mathrm{kg}$ body weight/day during pregnancy and showed that coumestrol decreased activity of intestinal alkaline phosphatase (IALP) in both

\section{MATERIALS AND METHODS}

Animals and coumestrol treatment. Pregnant ICR mice were obtained from Clea Japan (Tokyo, Japan), housed in polycarbonate cages and maintained in a temperature-controlled room (24 \pm 2 C) on a 14-h light (0500 h-1900 h)/ 10-h dark cycle. All animals were given free access to tap water and MF rodent feed (Oriental yeast, 
Tokyo, Japan). They received humane care as outlined in the "Guide for the Care and Use of Laboratory Animals” (Kyoto University Animal Care Committee according to NIH No. 86-23; revised 1999) and "Regulation on Animal Experimentation at Kyoto University”.

From 6.5 to 16.5 days post coitus (dpc), pregnant females were administered a daily dose of coumestrol (200 $\mathrm{\mu g} / \mathrm{kg}$ body weight/day, oral gavage, 11 times; Toronto Research Chemicals, Tronro, ON, Canada) dissolved in ethanol (Wako Pure Chemicals, Osaka, Japan) and purified olive oil (Wako; CM group) or ethanol dissolved in purified olive oil (5 ml/kg/day) as vehicle control (VC group) at $1200 \mathrm{~h}-1300 \mathrm{~h}$. As a normal control (NC group), pregnant females were kept under the same conditions without administration of either vehicle or coumestrol solution. The day on which pups were found in the morning was assigned as 1 day after parturition (dap), and the numbers of pups for each dam were reduced to 10 at 2 dap. At 17.5 dpc or 10 dap, blood samples were obtained for biochemical analysis by cardiac puncture under anesthesia by diethyl ether or avertin, and then the duodenum and jejunum were rapidly removed. Portions of these samples were immediately fixed in 10\% neutral-buffered formalin (Wako) for immunohistochemistry and enzyme histochemistry. The remaining portions of these samples were frozen in liquid nitrogen and stored at -80 C for semi-quantitative reverse transcriptase-polymerase chain reaction (RT-PCR).

Enzymehistochemical and immunohistochemical analyses. After formalin fixation, the duodenum and jejunum samples were dehydrated in a graded series of ethanol and embedded in paraffin (Histosec; Merck, Darmstadt, Germany). ALP activity and VDR protein expression in the duodenum and jejunum were examined using 
enzymehistoshemical and immunohistochemical analyses, respectively. These analyses were conducted as previously described (Kirihata et al., 2008).

Semi-quantitative RT-PCR. Total RNA was extracted from homogenized duodenum and jejunum samples from maternal mice using an RNeasy Mini Kit (Qiagen, Germantown, MD, USA). Complementary DNA (cDNA) was synthesized with oligo-(dT) primer using a SuperScript III First-Strand Synthesis System for RT-PCR (Invitrogen, Calisbad, CA, USA) and 2 pg RNA from each sample. The cDNA was quick-chilled on ice to denature the RNA-cDNA duplex. PCR was performed using a Platinum Super Mix Kit (Invitrogen). All of the above procedures were performed according to each manufacturer's protocol. The PCR products were electrophoresed in 2\% agarose gel and stained with $1 \mu \mathrm{g} / \mathrm{ml}$ ethidium bromide solution. A ready-load 100 bp DNA ladder (Invitrogen) was used as a molecular weight marker for electrophoresis. After electrophoresis, the gels were recorded with a digital recorder, and then the mRNA expression levels were semiquantified using ImageJ software (National Institute of Health, Bethesda, MD, USA). The relative abundance of specific mRNA was normalized by the abundance of glyceraldehydes 3-phophate dehydrogenase (GAPDH) mRNA. The primer pairs and PCR conditions used for IAP, c-fos, VEGF, VDR, epithelial Ca channel 1 (ECaC1), ECaC2 and GAPDH are same as those in the previous study (Kirihata et al., 2008).

Biochemical analysis. Each blood sample was stabilized at room temperature for $1 \mathrm{~h}$ and then centrifuged at $3000 \mathrm{rpm}$ for $15 \mathrm{~min}$. The serum was fractionated, and the serum $\mathrm{Ca}$ and inorganic phosphorus $(\mathrm{Pi})$ levels were measured using an automatic 
analyzer (Fuji Drychem 3500 V; Fuji Film, Tokyo, Japan) according to manufacturer’s instructions.

Statistical analysis. Statistical analysis was carried out by analysis of variance. This test was used to evaluate the interaction among three groups. When a difference among three groups was shown, the two-independent-sample $t$-test was applied to evaluate whether or not the difference was a treatment effect. Differences of $\mathrm{P}<0.05$ were considered significant.

\section{RESULTS}

\section{Intestinal ALP activity}

ALP activity was detected on the surface of the epithelia of villi and upper crypts. ALP activity weakened in the apical region of villi. ALP activity was not detected in the Brunner's glands in the duodenums. At 17.5 dpc, the duodenums of the CM group (Fig. 1c) showed weaker activity than those of the NC (Fig. 1a) and VC groups (Fig. 1b). In the jejunum, coumestrol also decreased ALP activity (Fig. 1d-f). In contrast, no remarkable differences were detected among the NC, VC and CM groups in both of the duodenum and the jejunum at 10 dap.

\section{Intestinal VDR expression}

No remarkable differences were detected in intestinal VDR expression in the duodenum and jejunum among the NC, VC and CM groups at 17.5 dpc and at 10 dap (not shown). In the duodenums, VDR was expressed strongly in the entire epithelium of villi compared with in the epithelium of the jejunum and scattered in the Brunner's glands. 
In the jejunums, VDR expression was detected in the entire epithelia of villi and crypts and declined from the villi top to the villi stem.

\section{Intestinal mRNA expression}

IAP, $c$-fos and VEGF mRNA was expressed both in the duodenum and jejunum. At 17.5 dpc, coumestrol administration decreased the mRNA expression of IAP, $c$-fos and VEGF compared with the NC and VC groups in the duodenum and jejunum $(\mathrm{P}<0.05$; jejunum, $\mathrm{P}<0.01$; duodenum; Table 1 ). At 10 dap, there were no significant differences in IAP mRNA expression in the duodenum and jejunum among the NC, VC and CM groups, but expression of $c$-fos in the duodeum and VEGF in the jejunum were decreased in CM group. VDR and ECaC2 mRNA was expressed in the duodenum and jejunum, but ECaC1 mRNA was not expressed. No significant differences were detected in VDR and ECaC2 mRNA expression among the NC, VC and CM groups at 17.5 dpc and at 10 dap (data not shown).

\section{Serum Ca and Pi}

No significant differences were detected in the serum $\mathrm{Ca}$ and Pi levels among the groups at $17.5 \mathrm{dpc}$ and at 10 dap (Table 2).

\section{DISCUSSION}

Estrogen regulates expression of some genes related to Ca metabolism, such as ALP and VDR. Intestinal ALP, which is encoded by IAP gene, increases Ca absorption in the jejunum and duodenum (Dulpuis et al., 1991; Halloran and De luca, 1981). Estrogen regulates activity and mRNA expression of IALP in rats (Matsumoto et al., 1997) and 
estrogen responsive genes, $c$-fos and VEGF, in mice (Hyder et al., 1991; Wang et al., 2009). Coumestrol has been shown to be an oestrogen agonist (Dodge et al., 1996; Jefferson et al., 2002; Kanno et al., 2004; Ye et al., 2003), and phytoestrogens increase intestinal Ca uptake via enhancement of ALP activity in ovariectomized mice (Mukherjee et al., 2006).

In this study, however, coumestrol at a dose of $200 \mu \mathrm{g} / \mathrm{kg}$ body weigh during pregnancy caused a decrease in IALP activity and mRNA expression of IAP, $c$-fos and VEGF in duodenum and jejunum of pre-delivery mice, although serum $\mathrm{Ca}$ and expression of VDR protein in the small intestine were not affected. Because phytoestrogens (at 100-1000 times of estradiol) compete effectively with endogenous estrogens, bind to the ER and prevent estrogen-stimulated growth in mammals (Kurzer and $\mathrm{Xu}, 1997)$, the effects of phytoestrogens on ALP activity may be related to the level of endogenous estrogen. In general, pregnancy induces a dramatic rise in estrogen, and serum estrogen increases with gestation but decreases after parturition. According to the previous (Kirihata et al., 2008) and present studies, coumestrol administration during pregnancy decreased the expression of IAP, $c$-fos and VEGF mRNA in both duodenum and jejunum at $17.5 \mathrm{dpc}$ and only in duodenum at 1 dap, resulting in the decreased activity of IALP in both duodenum and jejunum at 17.5 dpc and 1 dap. Thus, in the presence of high level of endogenous estrogen in mice before parturition, coumestrol administration may interrupt the ER-derived increase of ALP activity in mice around parturition. However, the antagonistic effects of coumestrol may not be maintained for lactating mice, because coumestrol administration had little effect on IALP activity in mice at 10 days after parturition.

Vitamin D and VDR also play important roles in Ca metabolism via regulation of 
ECaCs and IAP transcriptionally and the expression of VDR is regulated by estrogen (Bouillon et al., 2003). In this study, the VDR protein expression and the expressions of VDR and ECaC2 mRNA in mice were not affected by the administration of coumestrol, which agreed with the previous study (Kirihata et al., 2008). The expression of VDR mRNA is mediated by ER $\beta$ in human and rats, while the expression of murine $c$-fos and VEGF are induced by ER $\alpha$ dependent pathway (Jelinsky et al., 2003; Wang et al., 2009). It has been reported that the estrogen-antagonistic action of coumestrol observed in mouse brain is mediated by ER $\alpha$ (Jacob et al., 2001) and ER $\alpha$ mRNA expression is much more abundant in murine duodenum than ER $\beta$ (Duan et al., 2006; Kanno et al., 2004; Smith et al., 2008). Our results suggest that coumestrol regulates the expression of IAP mRNA and the activity of IALP through ER $\alpha$ in mice.

Recent studies in IALP deficient mice reported that lack of IALP does not result in Ca mal-absorption (Narisawa et al., 2003) but impairs intestinal barrier function (Goldberg et al., 2008). Because serum levels of Ca in mice were unchanged at 17.5 dpc, 1dap and 10 dap by coumestrol administration in both a previous (Kirihata et al., 2008) and the present study, it can be concluded that coumestrol at a dose of $200 \mu \mathrm{g} / \mathrm{kg}$ body weight during pregnancy does not have a significant effect on Ca metabolism in periparturient mice. However, laboratory studies in developmental animals have demonstrated the potential for adverse effects following exposure to high levels of soy isoflavones, although perimenopausal and early menopausal women may be more receptive to the therapeutic effects of isoflavones on bone loss prior to the diminution of ERs (Reinward and Weaver, 2006). Thus, feeding large amounts of phytoestrogen may be not recommended for pregnant animals, especially in pre-delivery periods, to prevent adverse effects on Ca metabolism. 
In summary, coumestrol administration during pregnancy may decrease the expression of IAP mRNA and the activity of IALP in the intestine of the pre-delivery mice through ER $\alpha$, but coumestrol had little effect on IALP activity at 10 days after parturition.

\section{Acknowledgement}

This work was supported in part by a Grant-in-Aid for Scientific Research (C) (No. 21580328) from Japan Society for the Promotion of Science.

\section{References}

Bouillon R, Van Cromphaut S, Carmeliet G. 2003. Intestinal Calcium absorption: Molecular vitamin D mediated mechanisms. J Cell Biochem 88: 332-339.

Dodge JA, Glasebrook AL, Magee DE, Phillips DL, Sato M, Short LL, Bryant HU. 1996. Environmental estrogens: Effects on cholesterol lowering and bone in the ovariectomized rat. J Steroid Biochem Mol Biol 59: 155-161.

Duan LP, Wang HH, Ohashi A, Wang DQ. 2006. Role of intestinal sterol transporters abcg5, abcg8, and npc1l1 in cholesterol absorption in mice: Gender and age effects. Am J physiol 290: G269-276.

Dupuis Y, Tardivel S, Porembska Z, Fournier P. 1991. Effect of some alkaline phosphatase inhibitors on intestinal calcium transfer. Int J Biochem 23: 175-180.

Farhan S, Sundeep K. 2005. Mechanisms of sex steroid effects on bone. Biochem Biophys Res Commun 328: 688-696.

Goldberg RF, Austen WG, Jr., Zhang X, Munene G, Mostafa G, Biswas S, McCormack M, Eberlin KR, Nguyen JT, Tatlidede HS, Warren HS, Narisawa S, Millan JL, Hodin 
RA. 2008. Intestinal alkaline phosphatase is a gut mucosal defense factor maintained by enteral nutrition. Proc Natl Acad Sci USA 105: 3551-3556.

Halloran BP, De Luca HF. 1981. Intestinal calcium transport: Evidence for two distinct mechanisms of action of 1,25-dihydroxyvitamin d3. Arch Biochem Biophys 208: 477-486.

Hyder SM, Stancel GM, Loose-Mitchell DS. 1991. Presence of an estradiol response region in the mouse c-fos oncogene. Steroids 56: 498-504.

Jacob DA, Temple JL, Patisaul HB, Young LJ, Rissman EF. 2001. Coumestrol antagonizes neuroendocrine actions of estrogen via the estrogen receptor alpha. Exp Biol Med (Maywood) 226: 301-306.

Jefferson WN, Padilla-Banks E, Clark G, Newbold RR. 2002. Assessing estrogenic activity of phytochemicals using transcriptional activation and immature mouse uterotrophic responses. J Chromatogr B Analyt Technol Biomed Life Sci 777: 179-189.

Jelinsky SA, Harris HA, Brown EL, Flanagan K, Zhang X, Tunkey C, Lai K, Lane MV, Simcoe DK, Evans MJ. 2003. Global transcription profiling of estrogen activity: Estrogen receptor alpha regulates gene expression in the kidney. Endocrinology 144: 701-710.

Kanno S, Hirano S, Kayama F. 2004. Effects of the phytoestrogen coumestrol on rank-ligand-induced differentiation of osteoclasts. Toxicology 203: 211-220.

Kirihata Y, Kawarabayashi T, Imanishi S, Sugimoto M, Kume S. 2008. Coumestrol decreases intestinal alkaline phosphatase activity in post-delivery mice but does not affect vitamin D receptor and calcium channels in post-delivery and neonatal mice. $J$ Reprod Dev 54: 35-41. 
Kovacs CS, Kronenberg HM. 1997. Maternal-fetal calcium and bone metabolism during pregnancy, puerperium, and lactation. Endocrine reviews 18: 832-872.

Kurzer MS, Xu X. 1997. Dietary phytoestrogens. Annu Rev Nutr 17:353-381.

Matsumoto HN, Yamamoto A, Iimura T, Oida S, Ezawa I, Sasaki S, Goseki-Sone M. 1997. Effects of ovariectomy on intestinal alkaline phosphatase expression in rats. $J$ Nutr Sci Vitaminol (Tokyo) 43: 529-539.

Morito K, Aomori T, Hirose T, Kinjo J, Hasegawa J, Ogawa S, Inoue S, Muramatsu M, Masamune Y. 2002. Interaction of phytoestrogens with estrogen receptors alpha and beta (ii). Biol Pharm Bull 25: 48-52.

Mukherjee M, Das AS, Das D, Mukherjee S, Mitra S, Mitra C. 2006. Role of oil extract of garlic (Allium sativum Linn.) on intestinal transference of calcium and its possible correlation with preservation of skeletal health in an ovariectomized rat model of osteoporosis. Phytother Res 20: 408-415.

Narisawa S, Huang L, Iwasaki A, Hasegawa H, Alpers DH, Millan JL. 2003. Accelerated fat absorption in intestinal alkaline phosphatase knockout mice. Molecular and cellular biology 23: 7525-7530.

Ososki AL, Kennelly EJ. 2003. Phytoestrogens: A review of the present state of research. Phytother Res 17: 845-869.

Reinwald S, Weaver CM. 2006. Soy isoflavones and bone health: a double-edged sword? J Nat Prod 69:450-459.

Smith A, Contreras C, Ko KH, Chow J, Dong X, Tuo B, Zhang HH, Chen DB, Dong H. 2008. Gender-specific protection of estrogen against gastric acid-induced duodenal injury: Stimulation of duodenal mucosal bicarbonate secretion. Endocrinology 149: 4554-4566. 
299 Wang M, Tan J, Coffey A, Fehrenbacher J, Weil BR, Meldrum DR. 2009. Signal 300 transducer and activator of transcription 3-stimulated hypoxia inducible factor-1alpha 301 mediates estrogen receptor-alpha-induced mesenchymal stem cell vascular 302 endothelial growth factor production. J Thorac Cardiovasc Surg 138: 163-171, 303 Ye SF, Saga I, Ichimura K, Nagai T, Shinoda M, Matsuzaki S. 2003. Coumestrol as 304 well as isoflavones in soybean extract prevent bone resorption in ovariectomized rats. Endocr Regul 37: 145-152.

306

307 
Figure legend

309

310 Figure 1. Alkaline phosphatase activity in the duodenums (a-c) and jejunums (d-f) of 311 mice at $17.5 \mathrm{dpc}$ in the normal control (a, d), vehicle control (b, e) and coumestrol (c, f) groups. Blue stains reflect alkaline phosphatase activity. Bars $=10 \mu \mathrm{m}$. V, villi; C, crypts; GB, Brunner’s glands. 
Table 1. The IAP/GAPDH, $c$-fos/GAPDH and

$V E G F / G A P D H$ ratio among three groups in the duodenum and jejunum at $17.5 \mathrm{dpc}$ and 10 dap.

\begin{tabular}{lccc}
\hline Genes & NC & VC & CM \\
\hline IAP & & & \\
at 17.5 dpc & & & \\
Duodenum & $0.60 \pm 0.14$ & $0.63 \pm 0.22$ & $0.32 \pm 0.10^{* *}$ \\
Jejunum & $0.94 \pm 0.19$ & $0.98 \pm 0.20$ & $0.69 \pm 0.23^{*}$ \\
at 10 dap & & & \\
Duodenum & $1.59 \pm 0.19$ & $1.61 \pm 0.18$ & $1.67 \pm 0.30$ \\
Jejunum & $0.95 \pm 0.12$ & $1.19 \pm 0.13$ & $1.10 \pm 0.15$ \\
\hline$c$-fos & & & \\
at 17.5 dpc & & & \\
Duodenum & $0.75 \pm 0.14$ & $0.68 \pm 0.17$ & $0.40 \pm 0.12^{* *}$ \\
Jejunum & $0.64 \pm 0.29$ & $0.61 \pm 0.21$ & $0.39 \pm 0.11^{*}$ \\
at 10 dap & & & \\
Duodenum & $1.25 \pm 0.27$ & $1.31 \pm 0.24$ & $0.46 \pm 0.12^{*}$ \\
Jejunum & $0.80 \pm 0.14$ & $1.03 \pm 0.11$ & $0.50 \pm 0.15$ \\
\hline
\end{tabular}

VEGF

at $17.5 \mathrm{dpc}$

Duodenum $\quad 0.41 \pm 0.09 \quad 0.34 \pm 0.07 \quad 0.22 \pm 0.04 * *$

Jejunum $\quad 0.61 \pm 0.20 \quad 0.64 \pm 0.22 \quad 0.30 \pm 0.09 *$

at 10 dap

Duodenum $\quad 1.30 \pm 0.21 \quad 1.09 \pm 0.17 \quad 1.23 \pm 0.32$

Jejunum $\quad 0.86 \pm 0.14 \quad 0.86 \pm 0.10 \quad 0.42 \pm 0.12 *$

Each value represents the mean value \pm SE ( $n=9$ per group at

$17.5 \mathrm{dpc}$ and $\mathrm{n}=11$ per group at $10 \mathrm{dap}$ ).

*: $\mathrm{P}<0.05$ vs. $\mathrm{NC}, * *: \mathrm{P}<0.01$ vs. NC.

NC, normal control; VC, vehicle control; CM, coumestrol 
Table 2. Serum $\mathrm{Ca}$ and $\mathrm{Pi}$ among the three groups at $17.5 \mathrm{dpc}$ and 10dap.

\begin{tabular}{cccc} 
Parameters & NC & VC & CM \\
\hline at $17.5 \mathrm{dpc}$ & & & \\
$\mathrm{Ca}(\mathrm{mg} / \mathrm{dl})$ & $10.79 \pm 0.49$ & $10.62 \pm 0.80$ & $10.31 \pm 0.71$ \\
$\mathrm{Pi}(\mathrm{mg} / \mathrm{dl})$ & $9.49 \pm 2.24$ & $7.69 \pm 1.69$ & $9.18 \pm 1.93$ \\
at $10 \mathrm{dap}$ & & \\
$\mathrm{Ca}(\mathrm{mg} / \mathrm{dl})$ & $10.27 \pm 0.45$ & $10.02 \pm 0.47$ & $10.19 \pm 0.42$ \\
$\mathrm{Pi}(\mathrm{mg} / \mathrm{dl})$ & $9.58 \pm 0.68$ & $9.36 \pm 0.78$ & $8.70 \pm 0.53$ \\
\hline Each value represents the mean value $\pm \mathrm{SE}(\mathrm{n}=9$ per group at \\
$17.5 \mathrm{dpc}$ and n=15 per group at 10 dap). \\
NC, normal control; VC, vehicle control; CM, coumestrol
\end{tabular}




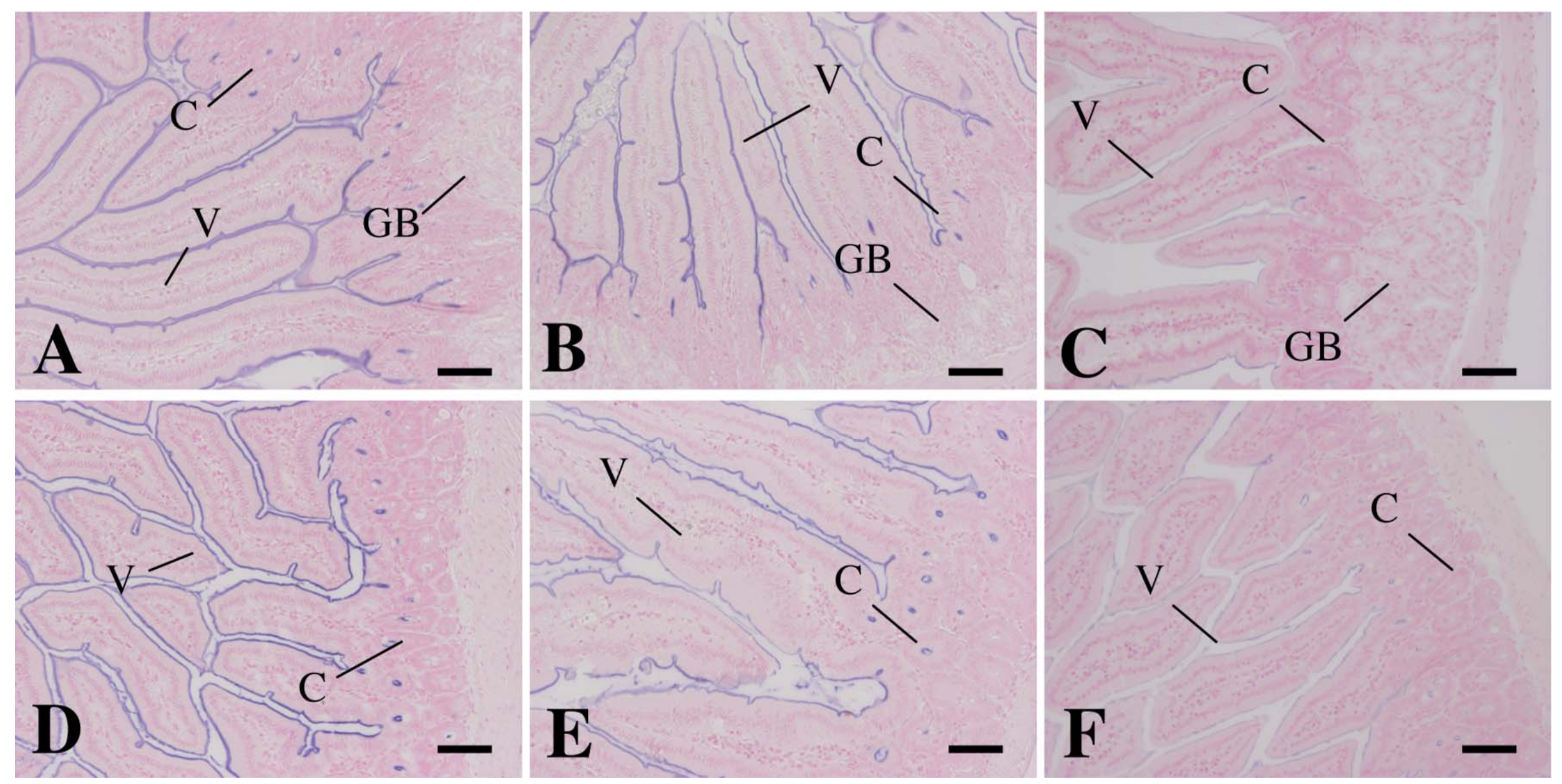

Figure 1 